Arq. Bras. Med. Vet. Zootec., v.59, n.2, p.541-542, 2007

\title{
Communication
}

[Comunicação]

\section{Serum biochemistry of an, atlantic Yellow-Nosed Albatross Thalassarche chlororhynchos (Gmelin, 1789)}

[Bioquímica do soro sangüíneo de um albatroz Thalassarche chlororhynchos (Gmelin, 1789)]

\author{
P. Baldassin, H. Gallo, C.B. Barbosa
}

Ubatuba Aquarium

Rua Guarani, 859

11680-000 - Ubatuba, SP

The identification and study of endangered species are key elements in defining global and regional priorities for both conservation of the species and their habitats (Croxall, 1998). Most albatrosses and several other seabird species are threatened for extinction. A great deal of animals are being cought and unintentionally drowned by longline fishing boats. The longline is a passive fishing, compared to others, but the seabirds capture is frequent (Póstuma and Neves, 2002). The estimated index of mortality is around 900 albatrosses per annum, at least. These deaths occur off from the Southeastern Brazilian coast, one of the commonest species attending longline boats. Commercial fisheries interact with seabirds in many ways; the most notable one is competing for food. Other ways of interaction are by incidental mortality and using fisheries waste as food. The fisheries waste that frequently causes the gathering of large numbers of seabirds would rarely or never be seen under natural conditions (Olmos, 1997). South American and South African fleets are responsible for just a small part of the total longline fishing effort in the South Atlantic, considering the most fishing effort is being undertaken by Japan and Taiwan. Consequently, the total number of Atlantic Yellow-Nosed Albatrosses killed by longline fishing in the South Atlantic Ocean is likely to be far higher than the available estimates (Cuthbert et al., 2003).

Atlantic Yellow-Nosed Albatross, Thalassarche chlororhynchos, breeds on Gough and all the islands in the Tristan da Cunha archipelago at the central South Atlantic Ocean (Cuthbert et al., 2003). In 1997, the archipelago and its territorial waters were proclaimed a Nature Reserve in terms of the Tristan da Cunha Conservation Ordinance (Ryan, 2000) and an UNESCO World Heritage Site for its international importance in breeding seabirds (Cuthbert et al., 2003). In the non-breeding season the animals disperse throughout the South Atlantic Ocean, mainly from $45^{\circ} \mathrm{S}$ to $15^{\circ} \mathrm{S}$. Some individuals have been recorded off the coast of Argentina, Brazil and the west coast of Southern Africa. This species is listed as endangered due to its very low breeding range.

Ubatuba Aquarium, located in the north of the Sao Paulo State, Brazil, has been working with rehabilitation of marine animal's since 1996. This is the second albatross needing medial cares received.

One male specimen was found by the Environmental Police and was brought to the Ubatuba Aquarium on September $9^{\text {th }}, 2005$. The animal was thin, dehydrated and alert, the body temperature was $37^{\circ} \mathrm{C}\left(97^{\circ} \mathrm{F}\right)$ and weighted $3 \mathrm{~kg}$. It was not able to be stand but its head and body were straight. A blood sample was collected for biochemistry serum analyses (Tab 1.) The packed cell volume was $23 \%$.

Recebido em 8 de novembro de 2006

Aceito em 5 de fevereiro de 2007

E-mail: veterinária@aquariodeubatuba.com.br 
Table 1. Blood serum biochemistry of a diseased albatross Thalassarche chlororhynchos (Gmelin, 1789) captured in Ubatuba, São Paulo

\begin{tabular}{ll} 
Cholesterol & $144 \mathrm{mg} / \mathrm{dl}$ \\
Triglycerids & $8 \mathrm{mg} / \mathrm{dl}$ \\
HDL LE & $46 \mathrm{mg} / \mathrm{dl}$ \\
LDL cholesterol & $97 \mathrm{mg} / \mathrm{dl}$ \\
VLDL cholesterol & $2 \mathrm{mg} / \mathrm{dl}$ \\
AST & $377 \mathrm{U} / 1$ \\
ALT & $113 \mathrm{U} / 1$ \\
Direct bilirubin & $0.2 \mathrm{mg} / \mathrm{dl}$ \\
Total bilirubin & $0.9 \mathrm{mg} / \mathrm{dl}$ \\
Alkaline phosphatase & $9 \mathrm{U} / 1$ \\
GGT & $35 \mathrm{U} / 1$ \\
Protein total & $1.2 \mathrm{~g} / \mathrm{dl}$ \\
Albumin & $0.3 \mathrm{~g} / \mathrm{dl}$ \\
Globulin & $0.9 \mathrm{~g} / \mathrm{dl}$ \\
Glucose & $199 \mathrm{mg} / \mathrm{dl}$ \\
Urea & $18 \mathrm{mg} / \mathrm{dl}$ \\
Creatinine & $0.4 \mathrm{mg} / \mathrm{dl}$ \\
Uric acid & $16.5 \mathrm{mg} / \mathrm{dl}$ \\
Creatine kinase & $109 \mathrm{U} / 1$ \\
\hline
\end{tabular}

On the first day, it refused to eat by itself, so feed was forced, initially with warm saline solution, $40 \mathrm{cc}$ added by vitamins. An antibiotic treatment was started using enrofloxacine $10 \mathrm{mg} / \mathrm{kg}$, IM. On next day, the animal was fed warm fish purée, visceras and vitamins. The animal did not respond to the treatment and died on the third day.

No related studies about biochemistry parameters of albatrosses were found, difficulting the veterinary staff to establish a correct diagnostic for this animal case. So, the biochemistry serum of that unique individual was presented in order to give some support for future studies.

Keywords: albatross, Thalassarche chlororhynchos, parameters, serum, rehabilitation

\section{RESUMO}

Colheu-se uma amostra de sangue de um albatroz Thalassarche chlororhynchos (Gmelin, 1789), recolhido pela Polícia do Meio Ambiente de Ubatuba, SP, para análises da bioquímica do soro. $O$ objetivo dessas análises foi o de apontar possíveis alterações dos parâmetros bioquímicos, visando facilitar futuras casas para reabilitação de aves. Nenhuma anormalidade foi encontrada e o animal morreu após três dias da captura.

Palavras-chave: albatroz, parâmetros sangüíneos, reabilitação

\section{ACKNOWLEDGEMENTS}

To Max Rondon Werneck and Bruno Giffoni, from Projeto Tamar-Ibama, and Carolina Donatti for critical reading.

\section{REFERENCES}

CROXALL, J.P.; GALES, R. An assessment of the conservation status of albatrosses. In: ROBERTSON, G.; GALES, R. (Eds) The Albatross: Biology and Conservation. Chipping Norton: Surrey Beatty and Sons, 1998. p.46-65.

CUTHBERT, R; RYAN, P.G.; COOPER, J. et al. Demography and population trends of the Atlantic yellow-nosed albatross. The Condor, v.105, p.439-452, 2003.
OLMOS, F. Seabirds attending bottom longline fishing off southeastern Brazil. IBIS, v.139, p.685-691, 1997.

PÓSTUMA, F.; NEVES, T. Avistagens de aves marinhas e acompanhamento da pesca de espinhel no BP Taihei Marú realizados durante o Cruzeiro Projeto Albatroz $n^{\circ} 09 / 02$. In: SIMPÓSIO DE BIOLOGIA MARINHA, 17., 2002, São Sebastião. Anais... São Sebastião, 2002. p.40. Resumo.

RYAN, P.G.; MOLONEY, C.L. The status of spectacled petrels Procellaria conspicillata and other seabirds at inaccessible island. Mar. Ornithol., v.28, p.93-100. 2000. 